\title{
Stratigraphic and geochemical constraints on the relative age of the Margaree Shear Zone in western Cape Breton Island, with implications for the early evolution of the Maritimes Basin*
}

\author{
Gregory Lynch \\ Geological Survey of Canada, Québec Geoscience Centre, \\ 2700 rue Einstein, C.P. 7500, Sainte-Foy, Québec G1V 4C7, Canada
}

Date Received May 8, 1995

Date Accepted October 2, 1995

\begin{abstract}
The Margaree Shear Zone is interpreted to be a thick, brittle-ductile low-angle extensional fault which was active in the Mid to Late Devonian at the time of initiation of the Maritimes Basin. In western Cape Breton Island, the fault separates two distinct basalt assemblages: low-grade to non-metamorphosed intra-continental basalts of the Upper Devonian Fisset Brook Formation occur in the hangingwall, whereas more primitive Ordovician-Silurian basalts, which were metamorphosed in Early Devonian time, to upper greenschist grade occur in the footwall. Major and trace element geochemistry from mylonitic basalt near the top of the shear zone demonstrate that the Fisset Brook Formation has been affected by the shearing. In particular the mylonites of Fisset Brook affinity are characterized by higher $\mathrm{Ti}, \mathrm{Zr}, \mathrm{P}, \mathrm{Y}$, and $\mathrm{Ga}$ contents, and lower $\mathrm{Ni}, \mathrm{Cr}$, and $\mathrm{Mg}$ values compared to the older basalts. Elemental plots are represented as ratios to eliminate enrichment or dilution factors caused by mobile elements such as $\mathrm{Si}, \mathrm{Ca}, \mathrm{K}$, and $\mathrm{Na}$. The age of the shear zone is further constrained in the region by an unconformity, which displays Tournaisian conglomerate of the Horton Group resting directly on the flat-lying mylonite, the former composed of clasts including mylonite as well as non-deformed vesicular basalt of the Fisset Brook Formation.
\end{abstract}

La zone de cisaillement de Margaree est interprétée comme une faille de distension subhorizontale cassantedéformable épaisse qui était active à l'époque du Dévonien moyen au Dévonien supérieur, au commencement de l'établissement du bassin des Maritimes. Dans l'ouest de l'île du Cap-Breton, la faille sépare deux assemblages basaltiques distincts : des basaltes intracontinentaux de faible teneur à non métamorphisés de la Formation du Dévonien supérieur de Fisset Brook sont présents dans la lèvre supérieure, alors que des basaltes plus primitifs de l'Ordovicien-Silurien, métamorphisés à l'époque du Dévonien inférieur, ayant une teneur en schiste vert supérieure sont présents dans la lèvre inférieure. L'analyse géochimique des éléments majeurs et des éléments traces du basalte mylonitique près du sommet de la zone cisaillée révèle que la Formation de Fisset Brook a été affectée par le cisaillement. Les mylonites ayant une affinité avec Fisset Brook, en particulier, sont caractérisés par des teneurs en $\mathrm{Ti}, \mathrm{Zr}, \mathrm{P}, \mathrm{Y}$ et $\mathrm{Ga}$ supérieures, ainsi que par des valeurs de $\mathrm{Ni}$, de $\mathrm{Cr}$ et de $\mathrm{Mg}$ inférieures, à celles des basaltes plus âgés. On a représenté les tracés d'exploration sous la forme de rapports afin d'éliminer les facteurs d'enrichissement et de dilution causés par les éléments mobiles comme le $\mathrm{Si}$, le $\mathrm{Ca}$, le $\mathrm{K}$ et le $\mathrm{Na}$. L'âge de la zone de cisaillement est en outre restreint dans la région par une discordance qui expose un conglomérat du Tournaisien du Groupe de Horton reposant directement sur la roche mylonitique à strates horizontales, le premier étant composé de clastes, dont de la mylonite ainsi que du basalte vésiculaire non déformé de la Formation de Fisset Brook.

[Traduit par la rédaction]

\section{INTRODUCTION}

Although strike-slip faults are recognized to have played an important role in the mid to late Paleozoic evolution of the Appalachian orogen (e.g., Bradley, 1982; Gibling et al., 1987; Malo and Bourque, 1993), features of extensional tectonics are increasingly being reported for the Late Devonian to Carboniferous evolution of the orogen, in Canada (Hamblin and Rust, 1989; Cawood, 1993; Lynch and Tremblay, 1994) and in the United States (Getty and Gromet, 1992; Snoke and Frost, 1990). Furthermore, the extensional characteristics in the Appalachians, with regards to sedimentation, metamorphism, and faulting, are similar to late-orogenic extensional features in the Caledonides of Europe (e.g., Séranne and Séguret, 1987; Fossen, 1992; Wilks and Cuthbert, 1994), where extension and detachment faulting have been linked to large scale strike-slip systems (Chauvet and Séranne, 1994).

In Cape Breton Island, the Margaree Shear Zone is interpreted as an important extensional fault linked to the early evolution of the Devonian-Carboniferous Maritimes Basin, and is one of the first extensional detachment faults documented in the Canadian Appalachians (Lynch and Tremblay, 1994) (Fig. 1). A similar extensional setting was proposed for the regional mid Devonian detachment of ophiolites in western Newfoundland (Cawood, 1989, 1993). Difficulties with dating of the Margaree Shear Zone and other similar

* Geological Survey of Canada Contribution No. 14295. 




Fig. 1. Location of study areas and detailed maps from Turner Brook (upper box), and Black Brook (lower box). Sample distribution (small boxes) is shown from within the Fisset Brook Formation (grey pattern with crosses), with chloritic schist and volcanic rocks from the Jumping Brook metamorphic suite highlighted by ruled pattern. Margaree Shear Zone is shown by fault trace with lobed motif, lobes are drawn on upper plate hangingwall side of the fault. Thrust faults (barbed) and steep brittle faults are also displayed.

faults are inherent from the characteristics which define these faults as extensional detachments; younger units in the hangingwall of the shear zone occur above older units in the footwall, with footwall units having been affected by higher grades of metamorphism indicating a missing crustal segment across the shear zone. Timing relations and the nature of contacts between young overlying volcanic and sedimentary rocks and underlying extensional core complexes are typically controversial topics. Debate, such as in examples from the western Cordillera (i.e., compare Hauge, 1985; Pierce, 1987; Pavlis and O'Neil, 1987; Wust, 1987), is usually centered on two competing views: (1) the clastic and volcanic succession unconformably overlies the mylonite, with the unconformity and older, flat-lying shear zone spatially coinciding, or (2) the mylonite is younger than the overlying clastic and volcanic rocks and bounds the detached basin during tectonic unroofing of underlying metamorphic units. The latter interpretation was proposed for the Upper Devonian Fisset Brook Formation in the hangingwall of the Margaree Shear Zone, based on field observations along the contact between the two, and because of the short time interval between the ages of the Upper Devonian unit and Early Devonian high grade metamorphism below the shear zone (Lynch and Tremblay, 1994). This paper presents new, whole-rock geochemical data from mylonitic basalt at the base of the Fisset Brook Formation which establishes the presence of sheared Fisset Brook Formation rocks within the Margaree Shear Zone, allowing clear constraints to be placed on the lower age limit of the shear zone. An empirical geochemical approach is taken. A site is also described along the Margaree Shear Zone from the Black Brook area of southwestern Cape Breton Island, where conglomerate of the Horton Group unconformably rests upon the shear zone, effectively establishing an upper age limit on the fault.

During the course of this study attempts were made to date mylonitic basalt within the Margaree Shear Zone by the ${ }^{40} \mathrm{Ar} /{ }^{39} \mathrm{Ar}$ method, but were unsuccessful due to the lack of appropriate minerals. Micaceous rocks from mylonitic basement units within the Margaree Shear Zone may be appropriate for ${ }^{40} \mathrm{Ar} /{ }^{39} \mathrm{Ar}$ dating, but petrographic evidence of abrasion and grain size reduction of micas within the shear zone demonstrate that shearing occurred in part after formation of the micas, below blocking temperatures. Alternatively, it is believed that the distinct immobile element geochemical signature of the mylonitized basalt is largely preserved, allowing recognition of the protolith, and therefore relative ages came to be reasonably well established.

\section{Geological setting}

The study area is underlain by Proterozoic to Cambrian basement rocks of the Avalon composite terrane (Williams and Hatcher, 1983; Keppie et al., 1992) and by Ordovician to Silurian sedimentary and volcanic cover successions (Lynch et al., 1993). The medium to high metamorphic grade Ordovician to Silurian assemblages together with high metamorphic grade gneisses in the region have been described as the Jumping Brook metamorphic suite, which was locally metamorphosed to amphibolite grade conditions in Late Silurian time (Doucet, 1983; Craw, 1984; Currie, 1987; Plint and Jamieson, 1989; Reynolds et al., 1989; Barr and Jamieson, 1991). Thrusting and telescoping of metamorphic domains occurred in the Early Devonian during the Acadian orogenic event (Lynch and Tremblay, 1992; Lynch et al., 1993). Shearing and thrusting of Early Devonian granite, dated by the U-Pb method on zircon at $376 \mathrm{Ma}$, place a close constraint on the lower age limit of thrusting (R. Horne, per- 
sonal communication). Greenschist grade metamorphic rocks beneath the Margaree Shear Zone were buried to 5 to $6 \mathrm{ki}$ lobars pressure in the Early Devonian (Lynch and Mengel, 1995), prior to extensional denudation and tectonic transport to the surface in Mid to Late Devonian time (Lynch and Tremblay, 1994). In the study area, the Margaree Shear Zone strikes approximately north-south and dips moderately to the west. Variably deformed basalt straddles the shear zone with greenschist grade Ordovician-Silurian basalt occurring to the east-northeast in the footwall, and vesicular, weakly- to non-metamorphosed Fisset Brook Formation basalt occurring to the west in the hangingwall.

\section{Fisset Brook Formation}

Bimodal basalt-rhyolite and interbedded silisiclastics of the Fisset Brook Formation occur in western Cape Breton Island (Fig. 1) and can be correlated widely across the Maritime provinces, forming the basal unit to the Maritimes Basin succession (Kelley and MacKasey, 1964; Howie and Barss, 1975; Blanchard et al., 1984). The age of the Fisset Brook Formation is constrained by radiometric and paleontological data which indicate a Late Devonian age (Kelley and MacKasey, 1964; Blanchard et al., 1984) of approximately $375 \mathrm{Ma}$ (Barr et al., 1995). The volcanic rocks are thought to be the eruptive equivalents to Late Devonian subvolcanic intrusions dated at $365+10 /-5 \mathrm{Ma}$ (Jamieson et al., 1986). Howie and Barss (1975) include the Fisset Brook Formation within the Horton Group, likely due to the presence of coarse conglomerate within the formation and apparent stratigraphic overlap with the Horton Group. However, a separate grouping may be warranted based on the widespread distribution and distinctive nature of the volcanic rocks. Volcanic rock geochemical characteristics suggest a within-plate continental setting for the Fisset Brook Formation (Currie, 1982; Dostal et al., 1983; Blanchard et al., 1984; Barr et al., 1995), which is consistent with field observations that show an unconformable contact with underlying Cambrian granite and other basement units (Lynch and Tremblay, 1992). The depositional environment proposed by Blanchard et al. (1984) is one of early explosive volcanism and clastic, alluvial fan type deposits, followed by basaltic eruptions with coeval fluvial and lacustrine sedimentation. Deposition apparently occurred within a horst and graben setting. Although a thickness of up to about $500 \mathrm{~m}$ is reported for the Fisset Brook Formation (Blanchard et al., 1984), at least one to possibly several important intraformational unconformities, as well as an unconformity with the overlying Horton Group suggest that original thicknesses are not preserved.

Basalts contain phenocrysts of plagioclase or olivine with augite, within a groundmass of fine grained calcic plagioclase. Flow textures are common as are massive basalts locally with ophitic to subophitic crystal aggregates. Flows are typically vesicular. Volcanic breccia and mafic pyroclastic deposits also occur. The basalts are variably metamorphosed and range from relatively unaffected units to those which contain abundant chlorite, epidote, actinolite, calcite, and minor hematite or pyrite. Metamorphism may include epidote with andradite (Blanchard et al., 1984). Zeolites are reported to occur within vesicles (Blanchard et al., 1984). Typically however, vesicules are partially or completely filled with fine grained epidote, chlorite, and calcite giving the rock a green spotted texture.

Rhyolite occurs as white to brick red massive units or may be flow-banded with complex flow textures. Quartz and alkali feldspar phenocrysts are common. The groundmass is locally altered to sericite and radiating bundles of clay minerals.

\section{Jumping Brook metamorphic suite}

The Jumping Brook metamorphic suite is an informal name for rocks which include Ordovician-Silurian volcanic-sedimentary successions in Cape Breton Island (Jamieson et al., 1987, 1990). It is equivalent to the Money Point Group of northern Cape Breton Island (Macdonald and Smith, 1980) and to the Sarach Brook metamorphic suite of central Cape Breton Island (Barr and Jamieson, 1991; Lynch et al., 1993), both of which have been dated by the U-Pb zircon method to be Late Ordovician to Early Silurian in age (Dunning et al., 1990; Keppie et al., 1992). In the study area of southwestern Cape Breton Island recent investigations have described the lithological, metamorphic, and structural characteristics of the Jumping Brook metamorphic suite (Connors, 1986; Currie, 1987; Jamieson et al., 1987; Plint and Jamieson, 1989; Jamieson et al., 1990; Barr and Jamieson, 1991; Lynch and Tremblay, 1992; Lynch et al., 1993; Lynch and Mengel, 1995). Volcanological and geochemical aspects of the rocks indicate that volcanic activity was likely subduction-related in an arc setting (Jamieson et al., 1990; Barr and Jamieson, 1991), and that rocks from the Faribault Brook section in the study area have a relatively primitive geochemical character (Connors, 1986).

In Cape Breton Island two thick units are generally recognized within the Jumping Brook suite; a lower unit which is predominantly volcanic in nature, and an upper clastic unit. A sheared contact separates these units. The volcanic unit is dominated by metabasalt which is pervasively sheared, isoclinally folded, and metamorphosed to upper greenschist and lower amphibolite grades. Interbedded siltstone, lapilli tuff, and minor rhyolite occur locally. Metadiorite sills and intrusions are dispersed throughout the succession and dominate the assemblage in places. The clastic unit typically includes well bedded siltstone, dark phyllite, or schist, as well as sandstone and conglomerate. Beds are thinly to thickly bedded, and graded bedding is common. Quartz-pebble conglomerate and wacke are widespread and typified by abundant blue quartz clasts. Arkose and conglomerate containing granitic clasts also occur but are less common. Chlorite and epidote are abundant in most mafic rocks, whereas garnet, chloritoid, biotite, and hornblende porphyroblasts are irregularly distributed. Andalusite and cordierite within clastic rocks occur in the proximity to the Devonian Salmon Pool pluton as contact metamorphic phases (Plint and Jamieson, 1989). 


\section{Margaree Shear Zone along Turner Brook}

The Margaree Shear Zone is well exposed along three branches of Turner Brook (Fig. 2) where mylonite, schist, and fault breccia crop out across a width of 1 to $2 \mathrm{~km}$. The mylonite dips moderately to the southwest and the true thickness of the shear zone is about 500 to $700 \mathrm{~m}$ (Figs. 3, 4, 5a). Mylonitic basement units include diorite, granitoid rocks, and metabasalt or chloritic schist from the Jumping Brook metamorphic suite. The outcrop section along the northwestern branch of the brook features a $100 \mathrm{~m}$ wide lozenge or fault horse of vesicular Fisset Brook basalt and redbed siliciclastics, fault bounded above by mylonitized Fisset Brook basalt and below by mylonitic Fisset Brook basalt and basement units. The mylonitic Fisset Brook basalt is finer grained and does not have the coarser schistose aspect of mylonitic basalt from the basement units, and is mineralogically characterized by a low-grade assemblage of chlorite-epidote-actinolite-calcite and very fine grained, abraided plagioclase (Fig. 5b,c). A stretching lineation is well developed. Porphyroclasts of plagioclase form asymmetrical winged inclusions which, together with asymmetrical shear bands (Fig. 5b), suggest southwest transport of the hangingwall. Large clots up to 1 to $2 \mathrm{~cm}$ in length and dominated by fine grained epidote form porphyroclasts, presumably derived from amygdules in the basalt. Cataclasite and fault breccia cover wide areas and feature a well indurated brown, oxidized rockflour matrix. Breccia clasts of sheared basalt may be as large as 20 to $30 \mathrm{~cm}$, and are sub-rounded to angular. Thin cataclasite layers may be entirely contained within the mylonite zone, and follow the principal fabric. Hematite is also common within the shear zone where it covers slip planes and has been overprinted by fault striations.

In the area surrounding Turner Brook, the Fisset Brook Formation consists of a thick succession of interbedded vesicular basalt, volcanic breccia, epiclastic sandstone, redbed siltstone and arkosic conglomerate. The succession is separated into lower and upper members by a distinct cobble conglomerate horizon, which marks an intraformational unconformity by virtue of vesicular basalt and redbed siltstone clasts derived from subjacent portions of the formation, as well as by the presence of a variety of basement derived clasts. No mylonite clasts were observed within the conglomerate. Although bedding within the Fisset Brook Formation also dips moderately to the west-southwest, the orientation and outcrop distribution of the conglomerate horizon appears to indicate that it is truncated by the shear zone (Fig. 2). Rhyolitic lapilli tuff occurs at the top of the succession.

\section{WHOLE-ROCK GEOCHEMISTRY}

Twelve new whole-rock analyses are presented in Table 1. Six are of mylonitic basalt from within the Margaree Shear Zone along Turner Brook (Fig. 2), and six are of relatively fresh vesicular basalt from the Fisset Brook Formation in the surrounding area. Analyses of major elements and $\mathrm{Ba}$,

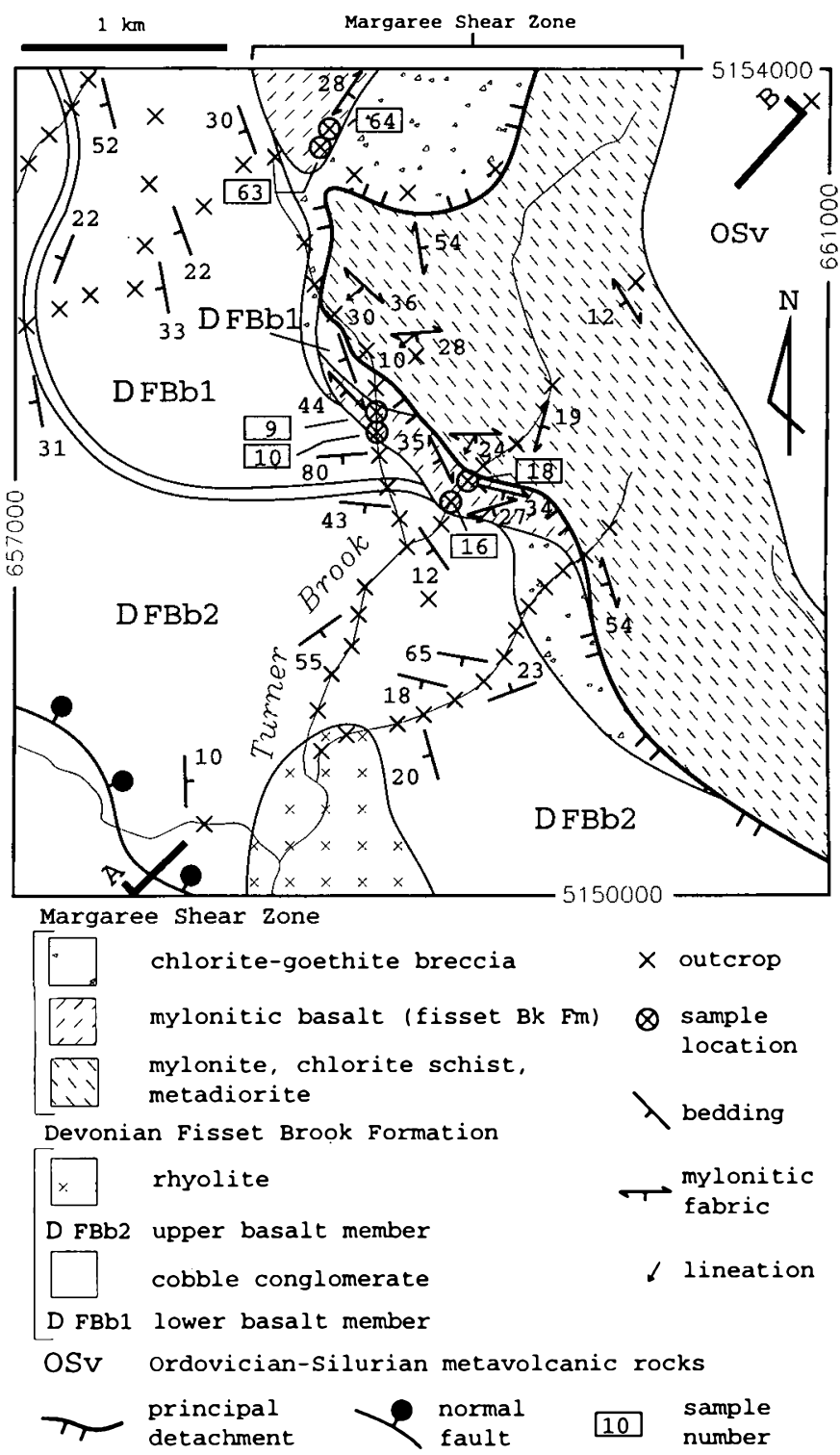

Fig. 2. Geological map along Turner Brook showing the distribution of the Margaree Shear Zone, and sample locations of mylonitic basalts.



Fig. 3. Cross section through Turner Brook, points $A$ and $B$ are located on Figure 2, and unit patterns as in legend of Figure 2, except for ball and spoke symbol which represents apparent dips of mylonite and bedding projected to the section and corrected for obliquety. 




Fig. 4. Lower hemisphere equal area plot of poles to mylonites and stretching lineations from Margaree Shear Zone in Turner Brook.

$\mathrm{Co}, \mathrm{Cr}, \mathrm{Cu}, \mathrm{Ga}, \mathrm{Ni}, \mathrm{Pb}, \mathrm{Rb}, \mathrm{Sr}, \mathrm{V}, \mathrm{Y}, \mathrm{Zn}$, and $\mathrm{Zr}$ were carried out on fused disks by $\mathrm{X}$-ray fluorescence at the analytical laboratories of the Institut National de la Recherche Scientifique in Sainte-Foy, Quebec.

An extensive geochemical database already exists for the Fisset Brook Formation and for the Jumping Brook metamorphic suite in this region. For comparison, analyses of mylonitic basalt and fresh basalt from this study are plotted with analyses of basalt from the Fisset Brook Formation of Blanchard et al. (1984), as well as with metabasalt data from the Jumping Brook metamorphic suite of Connors (1986). The analysed Ordovician-Silurian metabasalt rocks occur along Faribault Brook immediately north of the study area, and occur in the footwall of the Margaree Shear Zone. Because of the sheared nature of the rocks, the plots focus on elements which are considered to be relatively immobile or less mobile, such as $\mathrm{Al}, \mathrm{Ti}, \mathrm{Zr}, \mathrm{Y}, \mathrm{P}, \mathrm{Ga}, \mathrm{Ni}$, and $\mathrm{Cr}$. In particular, Ti (O'Hara and Blackburn, 1989) and $\mathrm{Al}$ (Selverstone et al., 1991) are recognized as immobile elements in geological settings where rocks have been converted to mylonite. Elements which are more susceptible to remobilisation ( $\mathrm{Si}$, $\mathrm{Ca}, \mathrm{K}, \mathrm{Na}, \mathrm{Rb}, \mathrm{Ba}$, and $\mathrm{Sr}$ ) are only briefly treated or not represented. Plots are also illustrated as elemental ratios in order to eliminate enrichment or dilution factors caused by the loss or introduction of mobile elements.

All samples are basic in composition, with a range of $\mathrm{SiO}_{2}$ from 41 to $57 \mathrm{wt}$ \% for the mylonites (Table 1), from 44 to $54 \mathrm{wt}$ \% for the Fisset Brook Formation, and from 44 to $51 \mathrm{wt}$. \% for the Jumping Brook metamorphic suite. Distinct geochemical fields can be ascribed to the Fisset Brook Formation and the Jumping Brook metamorphic suite, with generally limited overlap between the two. For the major elements, the Fisset Brook Formation and most of the mylonite samples are enriched in $\mathrm{TiO}_{2}$ and $\mathrm{P}_{2} \mathrm{O}_{5}$ when plotted against $\mathrm{Al}_{2} \mathrm{O}_{3}$ (Fig. 6a,b). Higher $\mathrm{MnO}$ is also recorded but values

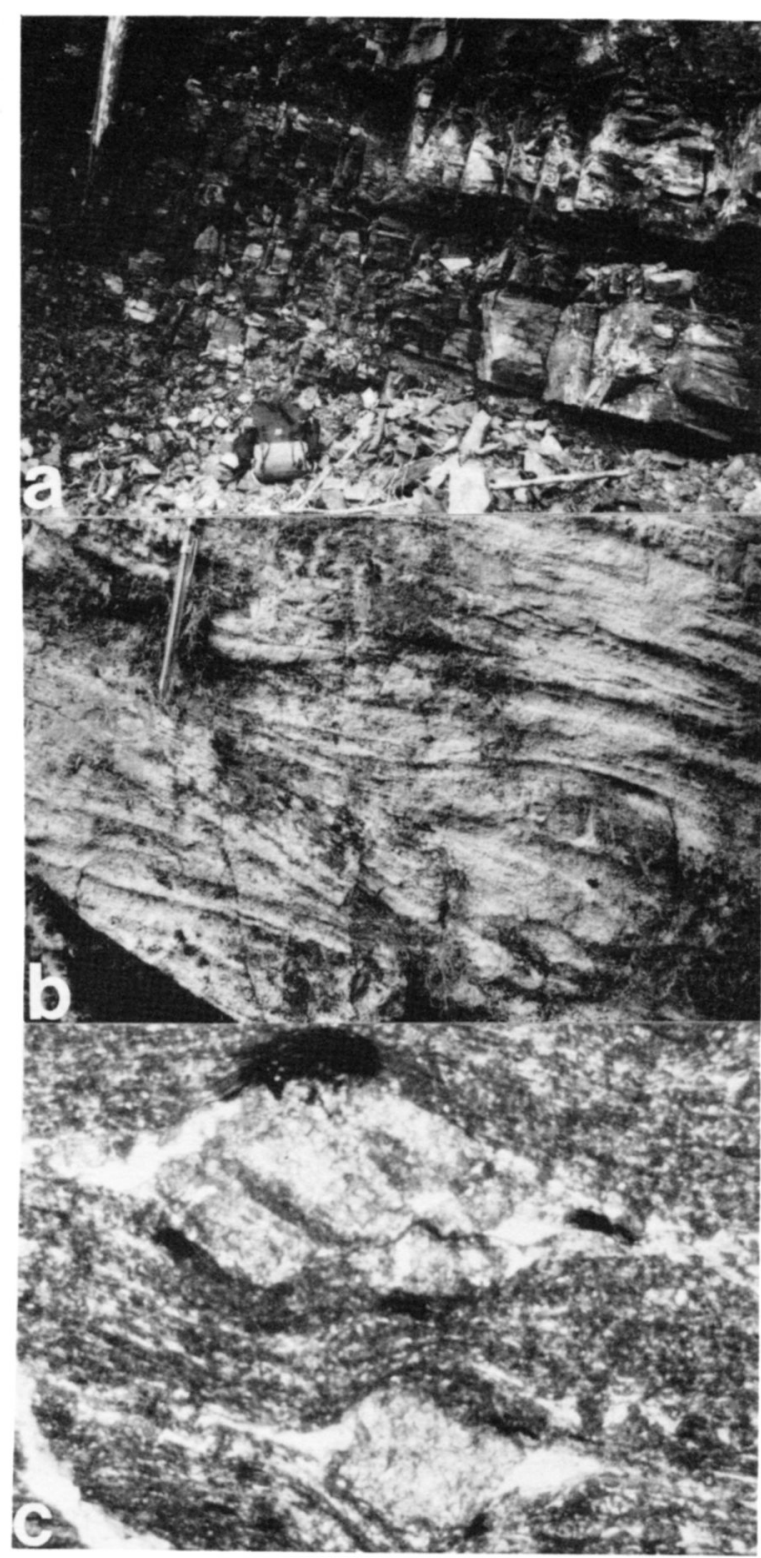

Fig. 5. (a) Outcrop photograph of Margaree Shear Zone displaying shallow-dipping layered nature of the mylonite (pack-sack at bottom-centre for scale); (b) asymmetrical shear bands in mylonitized Fisset Brook Formation basalt along upper portion of the Margaree Shear Zone in Turner Brook, indicating tops down to the southwest shear sense (pencil for scale); (c) photomicrograph of mylonitized Fisset Brook Formation basalt with porphyroclasts of epidote in fine grained sheared matrix of epidote-chlorite-actinolite and abraided plagioclase, pressure shadows are calcite (width of photograph is $1 \mathrm{~cm}$ ).

completely overlap the range occupied by the Jumping Brook suite (Fig. 6c). Conversely, the Jumping Brook suite has a distinctly higher $\mathrm{MgO}$ content, with the Fisset Brook Formation and mylonite samples showing similar low values (Fig. 6d). $\mathrm{CaO}$ is also enriched in the Jumping Brook suite relative to the Fisset Brook basalts and relative to all except one of the mylonite samples (Fig. 6e). The alkali content $\left(\mathrm{Na}_{2} \mathrm{O}+\mathrm{K}_{2} \mathrm{O}\right)$ is higher in the Fisset Brook samples, and is low in both the Jumping Brook and mylonite samples (Fig. 
Table 1. Whole-rock chemical analyses* of basalt from Fisset Brook Formation and Margaree Shear Zone

\begin{tabular}{|c|c|c|c|c|c|c|c|c|c|c|c|c|}
\hline \multirow[t]{2}{*}{ sample } & G449 & C186 & C446 & C435 & C465 & C100 & 9 & 10 & 16 & 63 & 64 & 18 \\
\hline & \multicolumn{6}{|c|}{ Fisset Brook Formation } & \multicolumn{5}{|c|}{ Margaree Shear Zone } & \\
\hline $\mathrm{SiO} 2(w t \%)$ & 47.33 & 45.25 & 42.44 & 49.72 & 51.11 & 44.91 & 57.57 & 49.71 & 49.84 & 51.09 & 48.91 & 41.31 \\
\hline $\mathrm{Al} 2 \mathrm{O} 3$ & 15.97 & 14.95 & 18.26 & 16.96 & 16.86 & 18.94 & 15.13 & 14.20 & 16.31 & 15.81 & 16.73 & 15.04 \\
\hline $\mathrm{FeOT}$ & 10.55 & 13.49 & 13.66 & 9.46 & 9.49 & 11.97 & 8.26 & 13.69 & 11.57 & 13.63 & 13.98 & 11.13 \\
\hline $\mathrm{MgO}$ & 6.75 & 6.27 & 5.97 & 6.81 & 6.60 & 7.10 & 5.00 & 8.35 & 5.49 & 6.49 & 5.84 & 7.04 \\
\hline $\mathrm{CaO}$ & 5.36 & 6.12 & 5.38 & 5.14 & 8.03 & 4.37 & 3.25 & 6.25 & 6.17 & 1.51 & 5.56 & 14.29 \\
\hline $\mathrm{Na} 2 \mathrm{O}$ & 4.51 & 4.41 & 3.37 & 5.60 & 2.79 & 3.96 & 2.08 & 0.23 & 3.91 & 3.61 & 2.71 & 1.63 \\
\hline $\mathrm{K} 2 \mathrm{O}$ & 3.81 & 2.83 & 3.05 & 0.76 & 0.56 & 1.79 & 2.35 & 0.10 & 0.08 & 0.08 & 0.07 & 0.08 \\
\hline TiO2 & 2.08 & 2.72 & 2.42 & 1.51 & 1.79 & 2.28 & 1.17 & 2.23 & 1.64 & 2.01 & 1.68 & 0.99 \\
\hline $\mathrm{MnO}$ & 0.69 & 0.38 & 0.29 & 0.52 & 0.12 & 0.42 & 0.20 & 0.36 & 0.19 & 0.24 & 0.22 & 0.22 \\
\hline P2O5 & 0.37 & 0.59 & 0.34 & 0.37 & 0.31 & 0.31 & 0.39 & 0.25 & 0.12 & 0.17 & 0.11 & 0.07 \\
\hline LOI & 3.71 & 3.10 & 5.30 & 3.61 & 3.58 & 4.55 & 3.77 & 5.16 & 4.77 & 4.46 & 4.53 & 7.52 \\
\hline TOTAL & 101.13 & 100.11 & 100.48 & 100.46 & 101.24 & 100.60 & 99.17 & 100.53 & 100.09 & 99.10 & 100.34 & 99.32 \\
\hline $\mathrm{Ba}(\mathrm{ppm})$ & 4118 & 716 & 614 & - & - & 254 & 372 & - & - & - & - & - \\
\hline $\mathrm{Rb}$ & 63 & 31 & 138 & 14 & - & 42 & 103 & 9 & - & 3 & 4 & 4 \\
\hline $\mathrm{Sr}$ & 645 & 541 & 509 & 353 & 304 & 387 & 200 & 454 & 127 & 44 & 105 & 172 \\
\hline Y & 29 & 36 & 21 & 29 & 31 & 27 & 40 & 116 & 40 & 41 & 39 & 32 \\
\hline $\mathrm{Zr}$ & 171 & 224 & 182 & 176 & 182 & 168 & 209 & 150 & 86 & 118 & 80 & 54 \\
\hline $\mathrm{Pb}$ & 5 & 5 & 5 & 17 & 7 & - & 16 & 30 & 5 & 9 & 9 & 9 \\
\hline $\mathrm{Ga}$ & 18 & 18 & 21 & 16 & 17 & 24 & 20 & 24 & 21 & 17 & 16 & 12 \\
\hline $\mathrm{Zn}$ & 578 & 337 & 173 & 333 & 90 & 330 & 98 & 138 & 88 & 101 & 96 & 83 \\
\hline $\mathrm{Cu}$ & 24 & 22 & 21 & - & 42 & 23 & 59 & - & 516 & 7 & 25 & 48 \\
\hline $\mathrm{Ni}$ & 63 & 39 & 61 & 89 & 55 & 43 & 39 & 45 & 107 & 127 & 128 & 182 \\
\hline Co & 42 & 48 & 49 & 41 & 40 & 47 & 46 & 86 & 73 & 101 & 91 & 71 \\
\hline $\mathrm{Cr}$ & 81 & 42 & 31 & 148 & 45 & 13 & 69 & 77 & 157 & 239 & 171 & 254 \\
\hline V & 332 & 324 & 268 & 240 & 216 & 286 & 151 & 291 & 314 & 330 & 353 & 191 \\
\hline
\end{tabular}

*Analysis by $\mathrm{X}$-ray fluorescence, $\mathrm{LOI}$ is loss on ignition, FeOT is iron expressed as $\mathrm{FeO}$.

6f). This last example is the only case where there is closer geochemical correspondence between the mylonites and the Jumping Brook samples, than between the mylonites and the Fisset Brook samples. However, due to the mobility and susceptibility to alteration of the alkalies and $\mathrm{Ca}$, they are likely the least reliable elements for identifying the protolith to the mylonites. Loss of alkalies is a typical effect of mylonitization (O'Hara and Blackburn, 1989).

Trace elements also help in distinguishing Fisset Brook Formation basalts from Jumping Brook suite basalts. The elements $\mathrm{Y}, \mathrm{Zr}$, and $\mathrm{Ga}$ are more abundant within the Fisset Brook Formation basalts and most of the mylonites, with the exception of sample \#18 (Fig. 7). The Jumping Brook suite is characterized by high $\mathrm{Ni}$ and $\mathrm{Cr}$ contents, with the mylonites plotting in the field of low values typified by the Fisset Brook Formation (Fig. 8).

Plots generated as elemental ratios (Figs. 9, 10) have two main advantages: (1) trends may be enhanced and groupings are more clearly established; and (2) enrichment and dilution factors, caused from the leaching or introduction of mobile elements, are reduced if the elements chosen for the plot are relatively immobile, thus showing the sample's original ratio signature. This second point is particularly important for this study as metamorphosed, non-metamorphosed, and mylonitized basalts are all compared. Major elements plotted as ratios with $\mathrm{Al}_{2} \mathrm{O}_{3}$ (Fig. 9) indicate that the higher Ti and $\mathrm{P}$, and lower $\mathrm{Mg}$ in the mylonites, compared to the Jumping Brook metamorphic suite, are likely primary features, and that the mylonites are geochemically similar to basalts from the Fisset Brook Formation. The same generalization can be made for the trace elements, where ratios of $Y / C r, Z r / C r$, and $\mathrm{Ga} / \mathrm{Cr}$ (Fig. 10) for the mylonites clearly plot in the field defined by the Fisset Brook Formation basalts, and are distinct from the ratios recorded in basalts from the Jumping Brook metamorphic suite.

\section{Upper age limit of the Margaree Shear Zone}

An upper age limit for the Margaree Shear Zone is established through contact relations with the Tournaisian Horton Group. The Horton Group unconformably covers the Margaree Shear Zone at map-scale, resting directly on footwall and 



Fig. 6. Major element geochemistry of Fisset Brook Formation (open circles), of mylonitic basalt (circles with $x$ ), and Jumping Brook metamorphic suite (squares). Data contained in Table 1, and compiled from Blanchard et al. (1984) and Connors (1986). Sample numbers included for mylonites.

hangingwall units east and west of the shear zone in the Turner Brook exposures. The Margaree Shear Zone has been mapped to the south of Turner Brook (Fig. 1), east of Lake Ainslie along Black Brook (Fig. 11) where it occurs as a thick, shallow-dipping mylonite zone beneath the Fisset Brook Formation. An unconformity with mylonite from the shear zone, is best exposed on Black Brook near Gillanders Mountain (Fig. 11). There, a clean contact can be observed (Fig. 12) with well sorted cobble conglomerate unconformably overlying thinly laminated mylonite. The clast-supported conglomerate contains rounded clasts up to 15 to $20 \mathrm{~cm}$ in size, of predominantly white quartzite and granitic fragments in a pebbly arkosic groundmass with abundant detrital muscovite. Mylonite clasts are subordinate but may be up to 20 to $30 \mathrm{~cm}$ in size and are typically sub-rounded to sub-angular. Rounded clasts of fresh to slightly epidotized, highly vesicular basalt are dispersed within the conglomerate, as well as subordinate clasts of redbed siltstone and arkose. The basalt clasts are most likely derived from the Fisset Brook Formation, indicating that the conglomerate is younger than the latter. The conglomerate is thickly bedded, with bedding running parallel to or at a slight angle to the mylonitic fabric, demonstrating that the mylonite was flat-lying at the time of Horton Group sedimentation. 


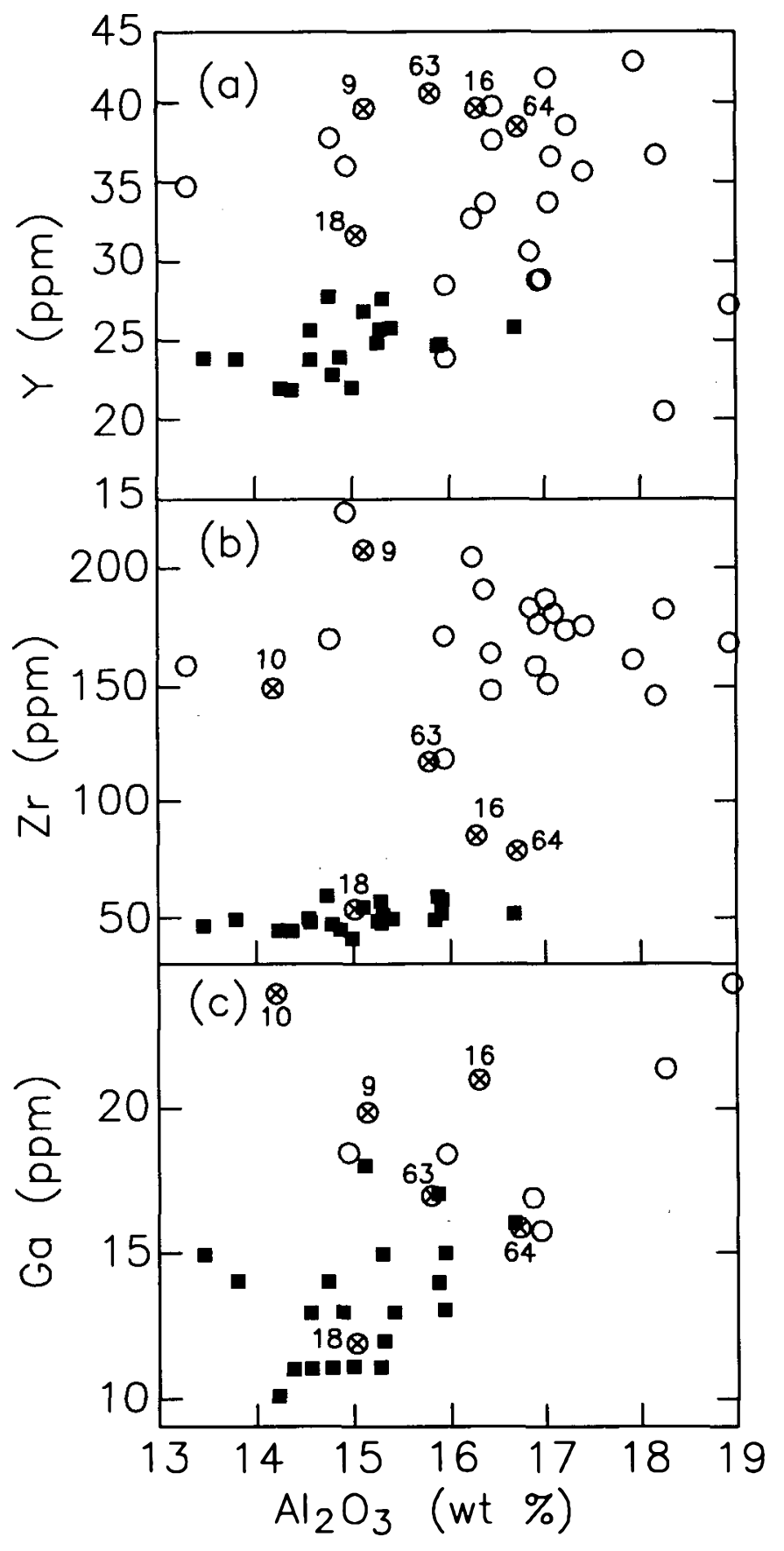

Fig. 7. Trace element geochemistry of Fisset Brook Formation (open circles), of mylonitic basalt (circles with $x$ ), and Jumping Brook metamorphic suite (squares). Data contained in Table 1, and compiled from Blanchard et al. (1984) and Connors (1986). Sample numbers included for mylonites.

The mylonite is exposed across an extensive succession of outcrops with a map width of approximately $2 \mathrm{~km}$ in a northeast trending belt (Fig. 11), and true thickness of the shear zone is at least $1 \mathrm{~km}$. Mylonite dips moderately to the northwest (Fig. 13), with stretching lineations plunging northeast-southwest (Fig. 13). Shear sense indicators such as C-S fabrics and winged inclusions suggest southwest transport of the hangingwall. The mylonite consists of predominantly

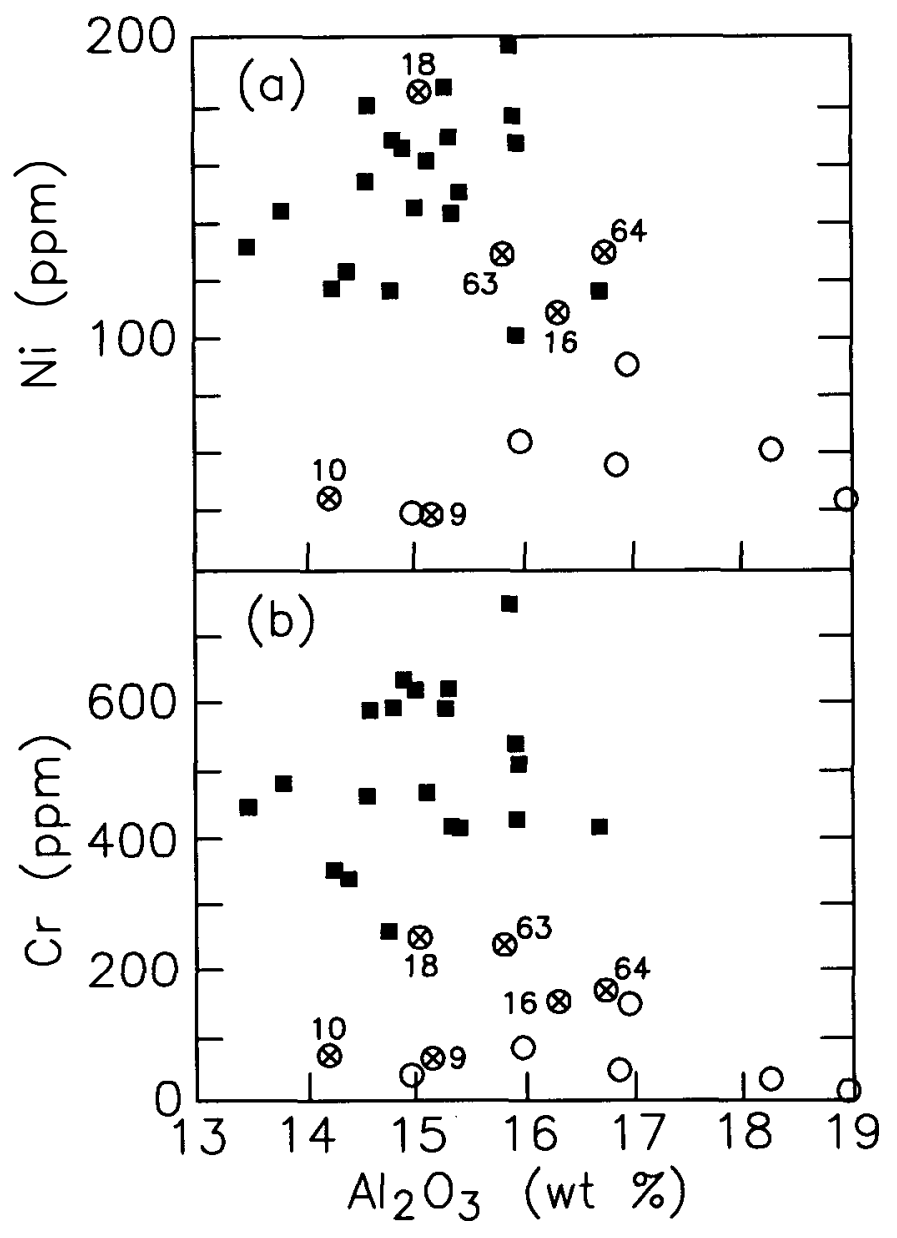

Fig. 8. $\mathrm{Cr}$ and $\mathrm{Ni}$ concentrations in Fisset Brook Formation (open circles), in mylonitic basalt (circles with $\mathrm{x}$ ), and from Jumping Brook metamorphic suite (squares). Data contained in Table 1, and compiled from Connors (1986). Sample numbers included for mylonites.

sheared conglomerate (of unknown origin) and possibly volcanic breccia or tuff. Fragments within the mylonite are highly strained showing extreme aspect ratios, and smooth rounded outlines. Quartzite is a common and easily identifiable clast type. Other types include granitic and dioritic rocks as well as possibly aphanitic volcanic clasts. The latter clast type is typically highly chloritized and epidotized, making unequivocal identification difficult. The size of clasts is highly variable. Although pebble or lapilli sizes are most abundant, intervals occur which contain abundant cobble-sized fragments. The protolith to these lithologies cannot be definitively identified at this stage, but the rocks clearly include conglomerate and volcanic units, which are most likely derived from the Ordovician-Silurian succession, although the Fisset Brook Formation cannot be ruled out. Fresh Fisset Brook Formation vesicular basalt occurs along the ridge top above the mylonite, immediately stratigraphically above a few outcrops of green, chloritic and epidote-rich, mylonitic basalt and white mylonitic rhyolite, possibly of the Fisset Brook Formation. 


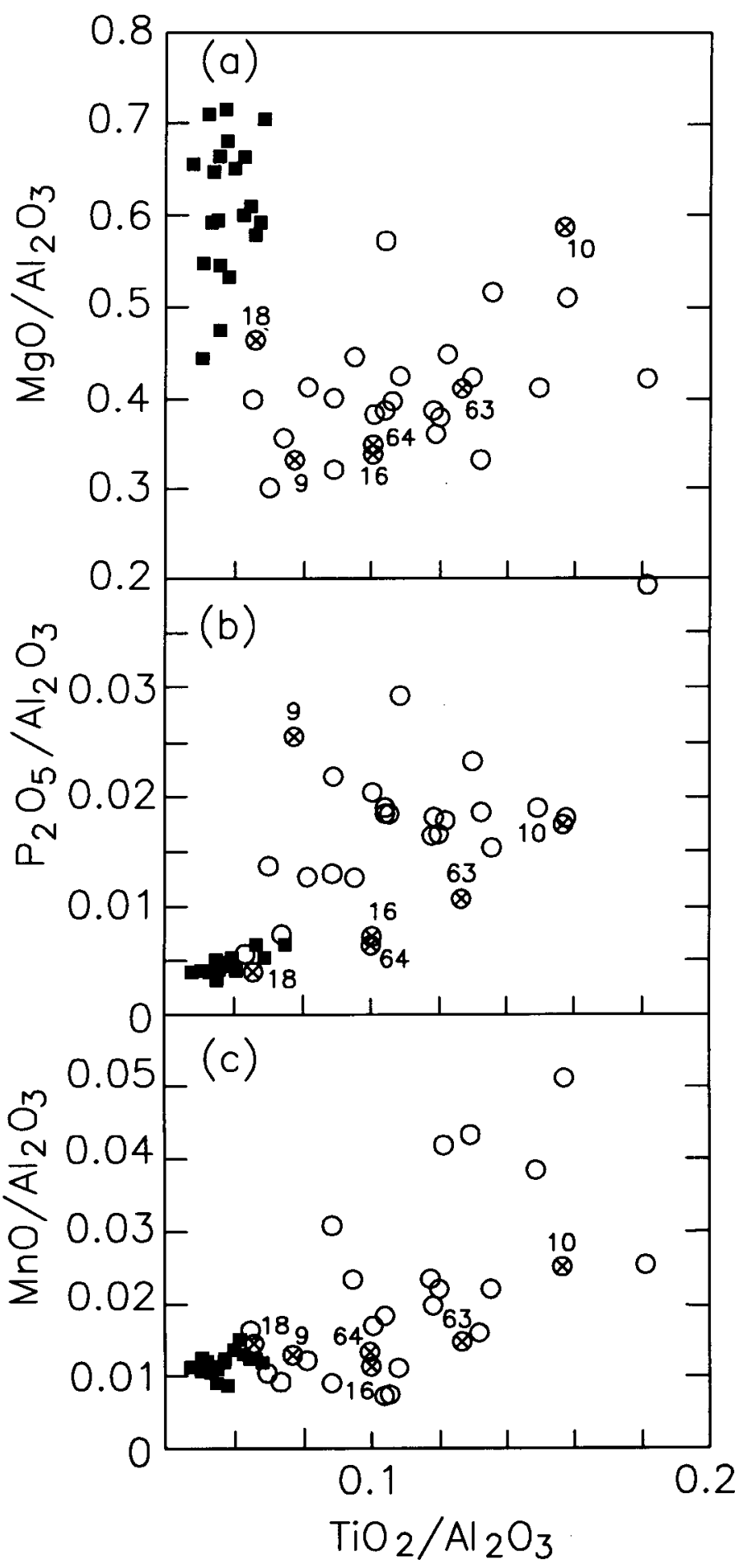

Fig. 9. Major element ratio plots for Fisset Brook Formation (open circles), for mylonitic basalt (circles with $x$ ), and for Jumping Brook metamorphic suite (squares). Data contained in Table 1, and compiled from Blanchard et al. (1984) and Connors (1986). Sample numbers included for mylonites.

\section{SUMMARY, CONCLUSIONS, AND TECTONIC SIGNIFICANCE}

A lower age limit is placed on the Margaree Shear Zone by the identification of mylonitic basalt from the Upper Devonian Fisset Brook Formation within the shear zone along Turner



Fig. 10. Trace element ratios for Fisset Brook Formation (open circles), for mylonitic basalt (circles with $x$ ), and for Jumping Brook metamorphic suite (squares). Data contained in Table 1, and compiled from Blanchard et al. (1984) and Connors (1986). Sample numbers included for mylonites.

Brook. The geochemical signature of the mylonites mimics that of the fresh basalts. Trends that are recorded in the sheared basalts which correspond to those in the non-deformed vesicular basalts of the Fisset Brook Formation include elevated $\mathrm{Ti}, \mathrm{P}, \mathrm{Zr}, \mathrm{Y}$, and $\mathrm{Ga}$ values and lower $\mathrm{Ni}, \mathrm{Cr}$, $\mathrm{Mg}$, and $\mathrm{Ca}$ values, relative to those reported for basalts 


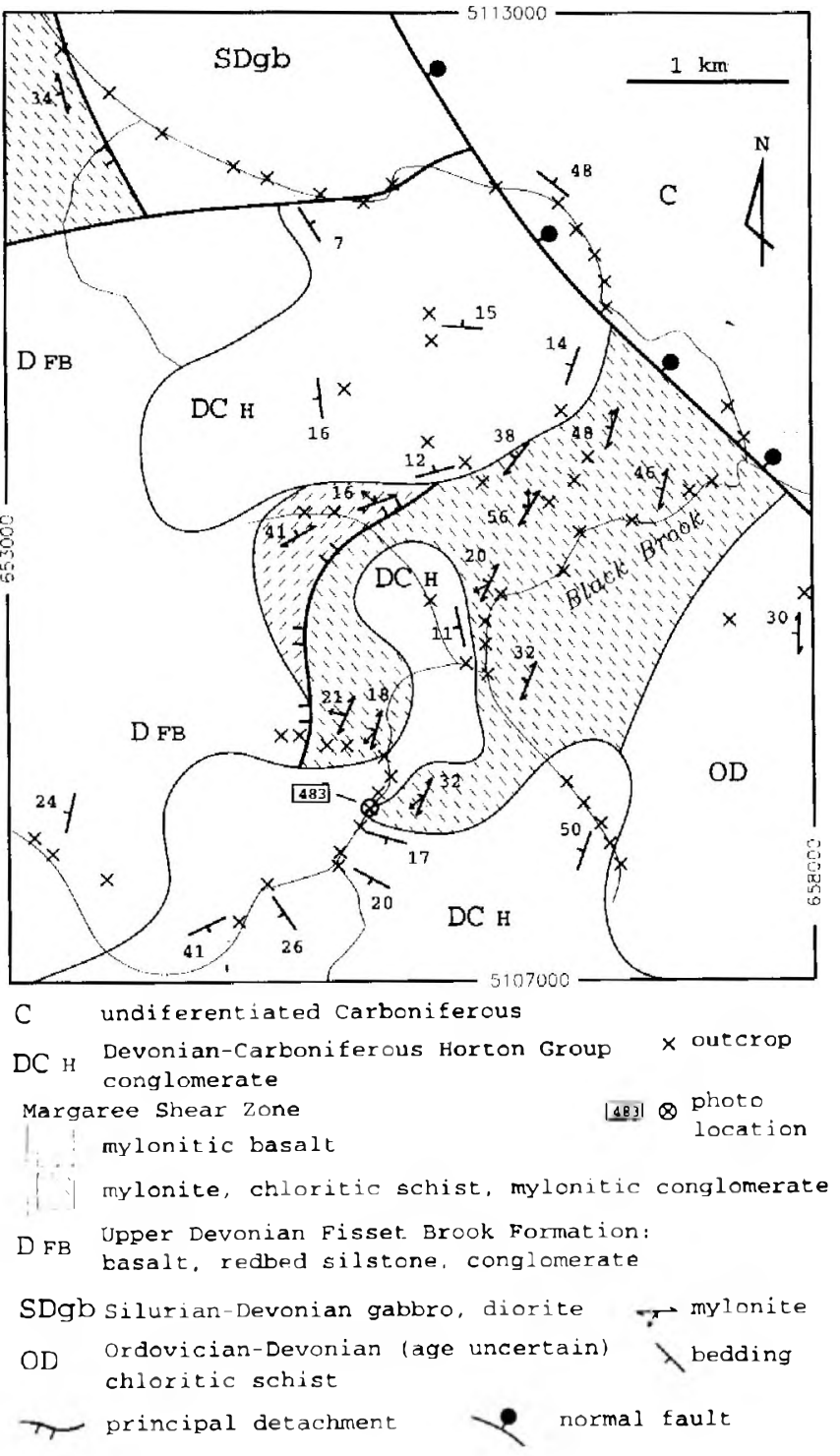

Fig. 11. Geological map along Black Brook showing structural features of the Margaree Shear Zone in relation to the Fisset Brook Formation and Horton Group.

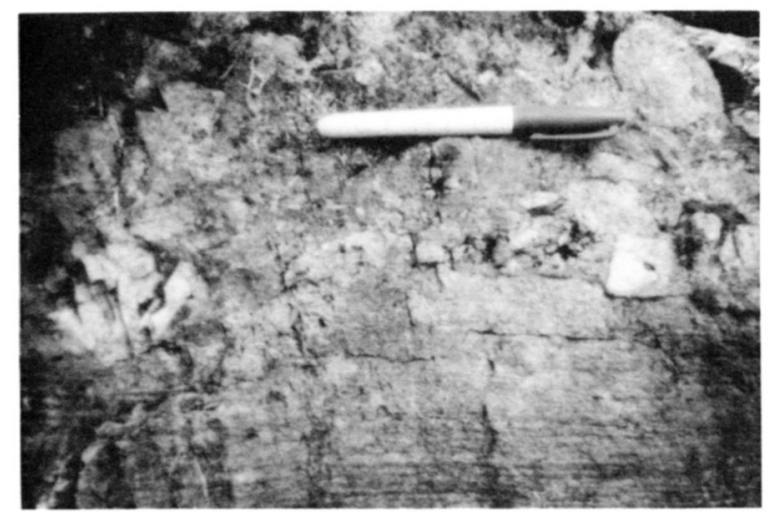

Fig. 12. Photograph of Horton Group conglomerate resting unconformably upon shallow-dipping laminated mylonite of the Margaree Shear Zone in Black Brook. Large white clasts on right and left side of photograph are quartzite.

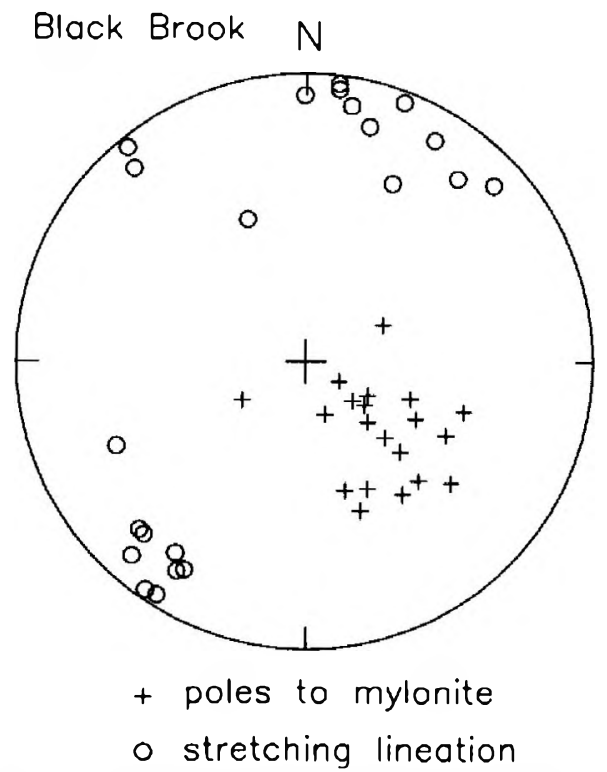

Fig. 13. Lower hemisphere equal area plot of poles to mylonites and stretching lineations from Margaree Shear Zone in Black Brook.

from older Ordovician-Silurian units. Ratio plots of elements correct for potential dilution or enrichment factors, and corroborate and enhance the above mentioned trends. Although there are apparently no truly immobile elements when considering mylonitic rocks (O'Hara and Blackburn, 1989; Selverstone et al., 1991; Badger, 1993), the consistency of the trends for a number of elements in this study suggests that the primary geochemical signature of the mylonites is largely preserved, identifying the mylonites as Fisset Brook basalt. The only exception recorded is in the plot of the combined alkalies which are generally recognized as being highly mobile in shear zones. An upper age limit is established by Horton Group conglomerates of Tournaisian age which unconformably overly the Margaree Shear Zone; the age of the shear zone is thus constrained to the interval 360 to $375 \mathrm{Ma}$.

The Margaree Shear Zone juxtaposes underlying rocks which were metamorphosed to relatively high grade conditions at or before $376 \mathrm{Ma}$, with overlying, low-grade to nonmetamorphosed, volcanic and sedimentary rocks deposited at approximately $375 \mathrm{Ma}$, effectively excising a significant portion of the upper crust (Fig. 14). Correspondingly, as illustrated in Figure 14, the Margaree Shear Zone may be classified as an extensional detachment fault which accommodated important crustal thinning during the early evolution of the Maritimes Basin.

\section{ACKNOWLedgements}

I would like to thank Christian Tremblay for his help in mapping portions of the Margaree Shear Zone. Acknowledgements are extended to Peter Giles for encouragement and suggestions on ways to study the early evolution of the Maritimes Basin. A preliminary version of this paper was read by Alain Tremblay and Denis Lavoie, whom I thank for their critical review. Journal referees Sandra Barr 


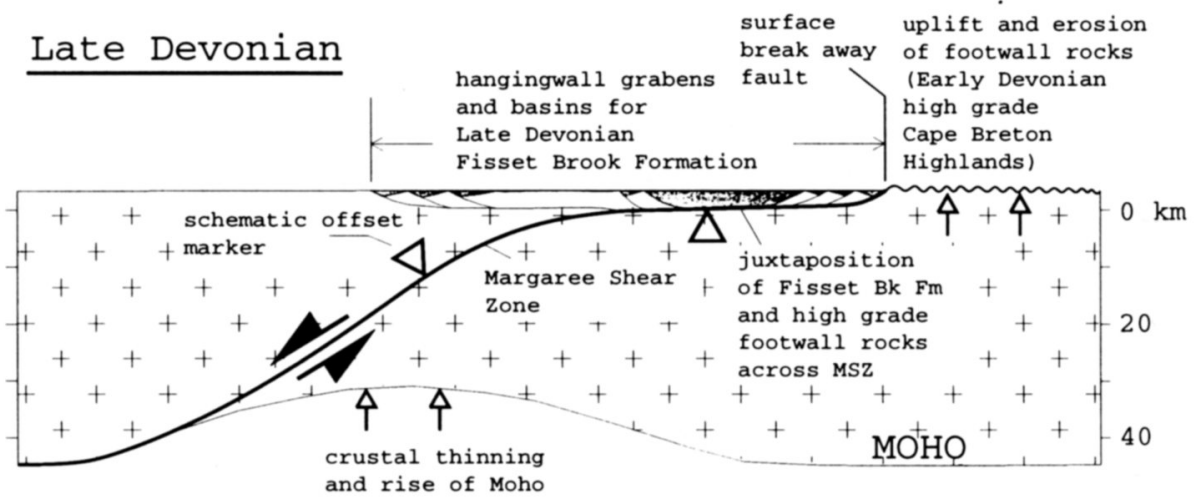

Fig. 14. Schematic diagram illustrating proposed tectonic setting for the Late Devonian Fisset Brook Formation and Margaree Shear Zone. Margaree Shear Zone accommodated crustal thinning with the Fisset Brook Formation deposited and sheared in the hangingwall. Early Devonian high grade assemblages of the Cape Breton Highlands were transported from depth and unroofed in the footwall. A corresponding rise in the Moho occurred during crustal thinning and early evolution of the Maritimes Basin, as imaged from deep crustal seismic lines (Lynch and Tremblay, 1994).

and anonymous also helped with their suggestions in improving the manuscript. Funding was received from the Geological Survey of Canada, from the Canada Nova Scotia Cooperation Agreement on Mineral Development, and from the Magdalen Basin NATMAP project.

BADGER, R.L. 1993. Fluid interaction and geochemical mobility in metabasalts; an example from the central Appalachians. Journal of Geology, 101, pp. 85-95.

BARR, S.M. and JAmieson, R.A. 1991. Tectonic setting and regional correlation of Ordovician-Silurian rocks of the Aspy terrane, Cape Breton Island, Nova Scotia. Canadian Journal of Earth Sciences, 28, pp. 1769-1779.

Barr, S.M., Cormier, C.F.M., and White, C.E. 1995. Devonian - Carboniferous volcanic and gabbroic rocks in Guysborough County and Cape Breton Island, Nova Scotia. Atlantic Geoscience Society Colloquium, Antigonish, Nova Scotia, Program with Abstracts, p. 7.

Blanchard, M.-C., Jamieson, R.A., and More, E.B. 1984. Late Devonian - Early Carboniferous volcanism in western Cape Breton Island, Nova Scotia. Canadian Journal of Earth Sciences, 21 , pp. 762-774.

Bradley, D.C. 1982. Subsidence in Late Paleozoic basins in the northern Appalachians. Tectonics, 1, pp. 107-123.

CAWOOD, P.A. 1989. Acadian remobilization of a Taconian ophiolite, western Newfoundland. Geology, 17, pp. 257-260.

-.-- 1993. Acadian orogeny in west Newfoundland: Definition, character, and significance. In The Acadian Orogeny: Recent Studies in New England, Maritime Canada, and the Autochthonous Foreland. Edited by D.C. Roy and J.W. Skehan. Geological Society of America, Special Paper 275, pp. 135 152.

Chauvet, A. and Seranne, M. 1994. Extension-parallel folding in the Scandinavian Caledonides: implications for late orogenic processes. Tectonophysics, 238, pp. 31-54.

Connors, K.A. 1986. Relationships between the sulphide mincrals, metamorphism, and deformation in the Faribault Brook area of the Cape Breton Highlands, Nova Scotia. B.Sc. thesis, Dalhousie University, Halifax, Nova Scotia, $105 \mathrm{p}$

$C_{R A w}, D .1984$. Tectonic stacking of metamorphic zones in Cheticamp River area, Cape Breton Highlands, Nova Scotia. Canadian Journal of Earth Sciences, 21, pp. 1229-1244.
Currie, K.L. 1982. Paleozoic supracrustal rocks near Chéticamp, Nova Scotia. Maritime Sediments and Atlantic Geology, 18, pp. 94-103.

---.- 1987. Contrasting metamorphic terranes near Cheticamp, Cape Breton Highlands, Nova Scotia. Canadian Journal of Earth Sciences, 24, pp. 2422-2435.

Dostal, J., DupUY, C., and KePpie, J.D. 1983. Uranium and thorium in Palcozoic rhyolites of Nova Scotia. Canadian Journal of Earth Sciences, 20, pp. 266-274.

Doucet, P. 1983. The petrology and geochemistry of the Middle River area, Cape Breton Island, Nova Scotia. M.Sc. thesis, Dalhousie University, Halifax, Nova Scotia.

Dunning, G.R., Barr, S.M., Raeside, R.P., and Jamieson, R.A. 1990. U-Pb zircon, titanite, and monazite ages in the Bras d'Or and Aspy terranes of Cape Breton Island, Nova Scotia: implications for magmatic and metamorphic history. Geological Society of America Bulletin, 102, pp. 322-330

Fossen, H. 1992. The role of extensional tectonics in the Caledonides of south Norway. Journal of Structural Geology, 14, pp. 10331046.

Getty, S.R. and Gromet, L.P. 1992. Geochronological constraints on ductile deformation, crustal extension, and doming about a basement-cover boundary, New England Appalachians. American Journal of Science, 292, pp. 359-397.

Gibling, M.R., Boehner, R.C., and Rust, B.R. 1987. The Sydney Basin of Atlantic Canada: an Upper Paleozoic strike-slip basin in a collisional setting. In Sedimentary Basins and Basin-Forming Mechanisms. Ediled by C. Beaumont and A.J. Tankard. Canadian Society of Petroleum Geologists, Memoir 12, Atlantic Geoscience Society Special Publication 5, pp. 269-286

Hamblin, A.P. and Rust, B.R. 1989. Tectono-sedimentary analysis of alternate-polarity half- graben basin-fill successions: Late Devonian-Early Carboniferous Horton Group, Cape Breton Island, Nova Scotia. Basin Research, 2, pp. 239-255.

Hauge, T.A. 1985. Gravity-spreading origin of the Heart Mountain allochthon, northwest Wyoming. Geological Society of America Bulletin, 96, pp. 1440-1456.

Howse, R.D. and Barss, M.S. 1975. Upper Paleozoic rocks of the Atlantic provinces, Gulf of St. Lawrence, and adjacent continental shelf. Geological Survey of Canada, Paper 7430 , pp. $35-50$.

Jamieson, R.A., van Breeman, O., Sullivan, R.W., and Currie, 
K.L. 1986. The age of igneous and metamorphic events in the western Cape Breton Highlands, Nova Scotia. Canadian Journal of Earth Sciences, 23, pp. 1891-1901.

Jamieson, R.A., Tallman, P.C., Marcotte, J.A., Plint, H.E., and Connors, K.A. 1987. Geology of the west-central Cape Breton Highlands. Geological Survey of Canada, Paper 87-13, 11 p.

Jamieson, R.A., Tallman, P.C., Plint, H.E., and Connors, K.A. 1990. Regional geological setting of pre-Carboniferous mineral deposits in the western Cape Breton Highlands, Nova Scotia. Geological Survey of Canada, Paper 90-8, pp. 77-99.

Kelley, D.G. and MacKasey, W.O. 1964. Basal Mississippian volcanic rocks in Cape Breton Island, Nova Scotia. Geological Survey of Canada, Paper 64-34, 10 p.

KePPIE, J.D., Dallmeyer, R.D., and KROGh, T.E. 1992. U-Pb and ${ }^{40} \mathrm{Ar} /{ }^{39} \mathrm{Ar}$ mineral ages from Cape North, northern Cape Breton Island: implications for accretion of the Avalon Composite Terrane. Canadian Journal of Earth Sciences, 29, pp. 277295.

LyNCH, G. and Mengel, F. 1995. Metamorphism of arsenopyritepyrite-sphalerite-pyrrhotite lenses, western Cape Breton Island, Nova Scotia. The Canadian Mineralogist, 33, pp. 105-114.

Lynch, G. and Tremblay, C. 1994. Late Devonian - Carboniferous detachment faulting and extensional tectonics in western Cape Breton Island, Nova Scotia, Canada. Tectonophysics, 238, pp. 55-69.

Lynch, G., Tremblay, C., and Rose, H. 1993. Compressional deformation and extensional denudation of Early Silurian volcanic overlap assemblages in western Cape Breton Island, Nova Scotia. In Current Research, Geological Survey of Canada, Paper 93-1D, pp. 103-110.

LYNCH, J.V.G. and TREMBLAY, C. 1992. Imbricate thrusting, reverse-oblique shear, and ductile extensional shear in the Acadian Orogen, central Cape Breton Highlands, Nova Scotia. In Current Research, Geological Survey of Canada, Paper 92-1D, pp. 1-100.

Macdonald, A.S. and Smith, P.K. 1980. Geology of Cape North area, northern Cape Breton Island, Nova Scotia. Nova Scotia Department of Mines and Energy, Paper 80-1.

Malo, M. and Bourque, P.-A. 1993. Timing of deformation events from late Ordovician to mid-Devonian in the Gaspe Peninsula. In The Acadian Orogeny: Recent Studies in New England, Maritime Canada, and the Autochthonous Foreland. Edited by D.C. Roy and J.W. Skehan. Geological Society of America, Special Paper 275, pp. 101-122.
O'Hara, K. and Blackburn, W.H. 1989. Volume-loss model for trace-element enrichments in mylonites. Geology, 17, pp. 524-527.

Pavlis, T.L., O'Neill, R.L., and Wust, S.L. 1987. Comment and reply on "Extensional deformation with northwest vergence, Pioneer core complex, central Idaho". Geology, 15, pp. 283284.

Pierce, W.G. 1987. The case for tectonic denudation by the Heart Mountain fault - a reply. Geological Society of America Bulletin, 99, pp. 552-568.

Plint, H.E. and JAmieson, R.A. 1989. Microstructure, metamorphism and tectonics of the western Cape Breton Highlands, Nova Scotia. Journal of Metamorphic Geology, 7, pp. 407 424.

Reynolds, P.H., Jamieson, R.A., BArR, S.M., and Raeside, R.P. 1989. An ${ }^{40} \mathrm{Ar} /{ }^{39} \mathrm{Ar}$ study of the Cape Breton Highlands, Nova Scotia: thermal histories and tectonic implications. Canadian Journal of Earth Sciences, 26, pp. 2081-2091.

Selverstone, J., Morteani, G., and Staude, J.M. 1991. Fluid channelling during ductile shearing; transformation of granodiorite into aluminous schist in the Tauern Window, eastern Alps. Journal of Metamorphic Geology, 9, pp. 419-431.

Séranne, M. and SÉguret, M. 1987. The Devonian basins of western Norway: tectonics and kinematics of an extending crust. In Continental Extensional Tectonics. Edited by M.P. Coward, J.F. Dewey, and P.L. Hancock. Geological Society of London, Special Publication 28, pp. 537-548.

SNOKE, A.W. and Frost, B.R. 1990. Exhumation of high pressure pelitic schist, Lake Murray Spillway, south Caroline: evidence for crustal extension during Alleghanian strikeslip faulting. American Journal of Science, 290, pp. 853. 881 .

WILKs, W.J. and Cuthrert, S.J. 1994. The evolution of the Hornelen Basin detachment system, western Norway: implications for the style of late orogenic extension in the southern Scandinavian Caledonides. Tectonophysics, 238, pp. 1-30.

Williams, H. and Hatcher, R.D., JR. 1983. Appalachian suspect terranes. In Contributions to the Tectonics and Geophysics of Mountain Chains. Edited by R.D. Hatcher, Jr., H. Williams, and I. Zietz. Geological Society of America, Memoir 158, pp. 33-53.

Editorial responsibility: P.S. Giles and G.L. Williams 